\title{
Taxon richness and biogeography of the Cladocera (Crustacea: Ctenopoda, Anomopoda) of Thailand
}

\author{
S. Maiphae ${ }^{1 *}$, P. Pholpunthin ${ }^{2}$, H.J. Dumont ${ }^{3}$ \\ ${ }^{1}$ Department of General Science, Faculty of Science, Prince of Songkla University, Hatyai, Songkhla, Thailand \\ ${ }^{2}$ Department of Biology, Faculty of Science, Prince of Songkla University, Hatyai, Songkhla, Thailand \\ ${ }^{3}$ Animal Ecology, Gent University, Ledeganckstraat 35, B-9000, Gent, Belgium
}

\begin{abstract}
At present, 99 species of cladocerans are known from Thailand, but up to ten more have not been identified to species, particularly in Chydorus, Ephemeroporus and Pleuroxus. Cosmopolitan species are a minority, while wide-ranging circumtropical taxa are an important element, beside species that only occur in the tropics-subtropics of two continents. At least three species are suspected of a neotropical - southeast Asian disjunction, while three more are provisionally considered endemic of Thailand. Daphnia, as usual in the tropics, is rare and reduced to the single D. lumholtzi.
\end{abstract}

Keywords: Cladocera, Taxonomy, Biogeography, Thailand, Southeast Asian - Neotropical disjunction

\section{Introduction}

Slowly, the Cladocera of tropical and subtropical regions are becoming better known. In Asia, classical works were published in the 1970-80s: India (Michael \& Sharma 1988), China (Chiang \& Du 1979), the Philippines (Mammaril \& Fernando 1978), Nepal (Dumont \& Van de Velde 1977), Sri Lanka (Fernando 1980) and Malaysia (Idris \& Fernando 1981, Idris 1983), and there has been little progress since. In Thailand, in contrast, studies only started in 1984 (Boonsom 1984), but later decades saw faunistic knowledge on the Cladocera boom (Pholpunthin 1997, Sanoamuang 1998, Pipatcharoenchai 2001, Saeng-aroon 2001, Sa-ardrit 2002, Kotov \& Dumont 2000, Kotov \& Sanoamuang 2004a, Kotov \& Sanoamuang 2004b, Sa-ardrit \& Beamish 2005, Sanoamuang \& Faitakum 2005, Maiphae 2005, Maiphae et al. 2005, Kotov et al. 2005a, 2005b Sinev et al., 2007), ultimately overshooting the 100 species mark. However, the classification and level of morphological resolution during this period was revolutionized (Kotov 2003, Van Damme et al. 2003, Kotov \& Hollwedel 2004, Van Damme et al.2005), such that the validity of a number of named taxa needs re-evaluation. The present study aims to update the species list of Thailand. We examine the

\footnotetext{
*Corresponding author: E-mail: supiyanit.m@psu.ac.th
}

validity of suspect or critical taxa, and include notes on the biogeography of the Thai cladoceran fauna.

\section{Materials and methods}

\section{The study area}

Thailand is situated on the Indo-Chinese Peninsula between latitude $97^{\circ} 30^{\circ} \mathrm{E}$ to $105^{\circ} 45^{\circ} \mathrm{E}$, and longitude $5^{\circ} 45^{\circ} \mathrm{N}$ to $20^{\circ} 30^{\circ} \mathrm{N}$. The climate is hot and rather humid, with a monsoonal regime: 80 percent of total annual rainfall occurs between May and October. The country is divided into five regions: the north, the northeast, the west, the center and the south.

\section{Examination of specimens}

Our investigation is based on about 900 qualitative plankton samples, collected from 96 sites in Thailand (Fig. 1) during 1999-2007 by Maiphae. Of which, 66 sites from the south (S01-S066), nine sites from the north (N01-N09), nine sites from the center (C01-C09) and 12 sites from northeast Thailand (NE01-NE012), including specimens from Kudthing swamp, northeastern Thailand (Saeng-aroon 2001), and voucher specimens of Alona affinis, A. cambouei, A. cheni, A. karelica, A. verrucosa, Macrothrix paulensis, M. triserialis and M. spinosa, from Singapore, Malaysia, Burma, Brazil, Czechoslovakia and Spain. In addition, data from 


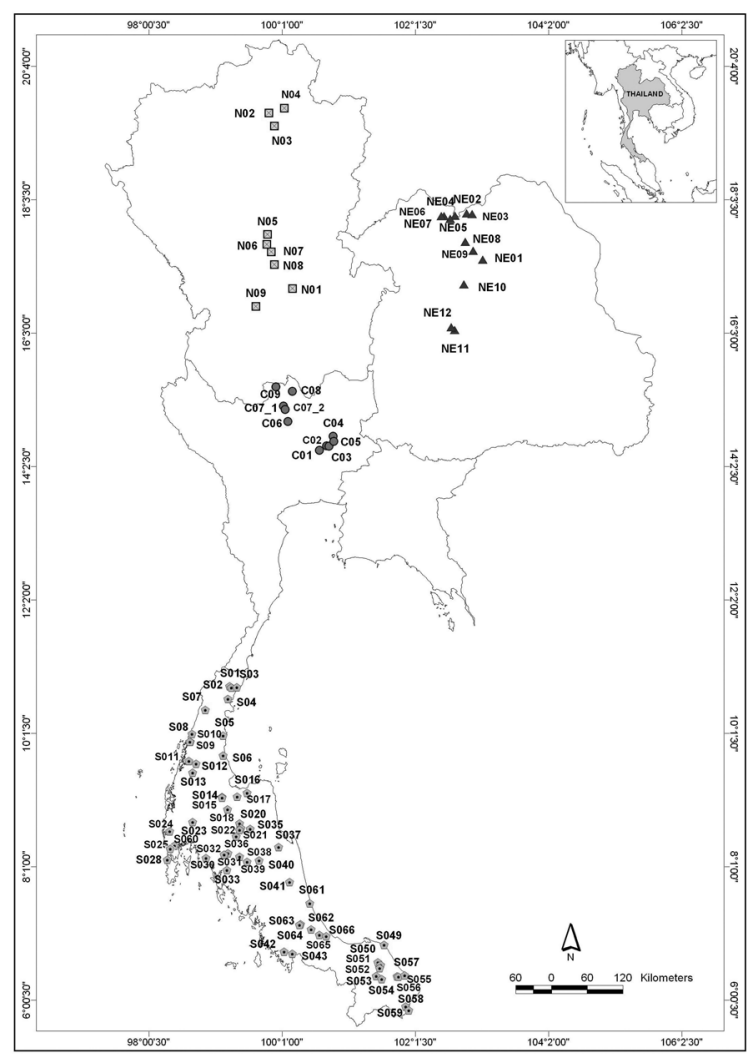

Fig. 1. Sampling sites

Pholpunthin (1997), Sanoamuang (1998), Saeng-aroon (2001), Sa-ardrit (2001), Pipatcharoenchai (2001), Saardrit \& Beamish (2005), Kotov \& Sanoamuang (2004), Maiphae (2005), Maiphae et al. (2005a, 2005b), Sanoamuang \& Faitacum (2005), Kotov et al. (2005) and Sinev et al. (2007) were used for the comparison.

The taxonomic status of species was examined and reevaluated by a detailed morphological study. Permanent slides of complete and dissected specimens were prepared and deposited in the PSU Natural History Museum, Prince of Songkla University, Thailand (Catalogue Code: PSUZC-PK1SM). Drawings were made using a camera lucida connected to a compound microscope. The species richness count is based only on fully named species.

The distribution range of each species is evaluated by biogeographical regions: Oriental, Palearctic, Australian, African, Neotropical and Nearctic regions. An attempt is made to discuss the events that may have led to present-day cladoceran distribution. Information from studies such as Chiambeng (2004) and Chiambeng \& Dumont (2005) was included in the analysis.

\section{Abbreviations}

The following abbreviations are used in all illustrations: EX=Exopodite, EN=Endopodite, IDL=Inner distal lobe, $\mathrm{ODL}=$ Outer distal lobe

\section{Results and Discussions}

The list of cladoceran species from Thailand has been changing with the level of morphological resolution. A total of 99 species in 38 genera and seven families are now on record (Table 1). The species lists still represent an underestimate, since a number of species remain inadequately defined (Maiphae et al. 2005, Adamowicz \& Purvis 2005). A brief discussion of morphological and biogeographical notes is presented below.

\section{Notes on taxonomy of some taxa}

Some specimens cannot currently be identified to species: Karualona sp.1 (Sa-ardrit 2001), Karualona sp.2 (Sa-ardrit \& Beamish 2005), Leydigia sp. (Maiphae 2005 and Maiphae et al. 2005), Leydigiopsis sp. (Sanoamuang 1998, Sa-ardrit 2001, Maiphae 2005 and Maiphae et al. 2005) and Macrothrix sp.1 and Macrothrix sp.2 (Sa-ardrit 2001). These have been found in too few specimens to evaluate their status. The rarity of such species and limited available material are major problems. To overcome these, further intensive sampling should be made. From the present data, however, it appears that some "species" are made up of more than one taxon. For example, the Alona verrucosa from southern Thailand clearly represents two species, roughly separable by the following combination of characters: 1) shape ovoid, ventral setae relatively short, antennule compact and postanal margin of postabdomen longer than anal margin (PK1SM004-01: Fig. 2a); and 2) shape rounded, ventral setae relatively longer posteriorly, antennule elongated and postanal margin of postabdomen as long as anal margin (PK1SM004-02: Fig. 2b). However, these data are insufficient to define their status. More detailed morphological information is needed. If all species in the list above were fully identified, the cladoceran fauna in Thailand would reach close to 110 species.

Some species had previously been given a wrong name. This applies to Alona cheni Sinev, 1999, Alona archeri Sars, 1888 and Alona cf. cambouei De Guerne \& Richard, 1893. In the case of Alona cheni, the name "Alona costata" had been used previously. Following the key for Malaysia (Idris 1983), which shows sac-like lateral head pores as the main diagnostic characters, any Alona with this character was formerly named Alona costata. 
Table 1. The Cladocera found in Thailand and distribution of each species. (Reference code: 1=Pholpunthin, 1997; 2=Sanoamuang, 1998; 3=Saeng-aroon, 2001; 4=Sa-ardrit, 2001; 5=Pipatcharoenchai, 2001; 6=Sa-ardrit \& Beamish, 2004; 7=Kotov \& Sanoamuang, 2004; 8=Kotov, Maiphae \& Sanomuang, 2005; 9=Maiphae, $2005 ; 10$ =Maiphae et al., 2005; 11=Sanoamuang \& Faitacum, 2005; 12=Kotov, Stifter \& Sanoamuang, 2005; 13=Sinev et al.,2007: Geographical distribution code: $\mathrm{O}=$ Oriental; $\mathrm{P}=$ Palearctic; $\mathrm{A}=$ Australian; $\mathrm{Af}=\mathrm{African}$; $\mathrm{N}=$ Neotropics, $\mathrm{Ne}=$ Nearctic).

\begin{tabular}{|c|c|c|c|c|c|c|c|c|}
\hline & Species & & & stril & butic & ons & & Notes \\
\hline & & $\mathrm{O}$ & $\mathrm{P}$ & $\mathrm{A}$ & Af & $\mathrm{N}$ & $\mathrm{Ne}$ & \\
\hline & Order Anomopoda & & & & & & & \\
\hline & Family Bosminidae & & & & & & & \\
\hline 1 & Bosmina fatalis: 5 & + & & & & & & \\
\hline 2 & B. longirostris: $5,9,10$ & + & + & + & + & + & + & circumtropical \\
\hline 3 & B. meridionalis: $2,5,6,9,10,11$ & + & & & & & & \\
\hline 4 & $\begin{array}{l}\text { Bosminopsis deitersi: } 1,2,3,4,5,6,9 \text {, } \\
10,11\end{array}$ & + & & + & + & + & & cosmopolitan \\
\hline & Family Chydoridae & & & & & & & \\
\hline 5 & Alona affinis: 2, 3, 4, 6, 9, 10, 11 & + & + & + & + & + & & \\
\hline 6 & A. archeri: $1,9,10$ & + & & + & & & & \\
\hline 7 & A. cf. cambouei: 2,9 & + & & & + & & & \\
\hline 8 & A. cheni: 9 & + & & & & & & \\
\hline 9 & A. cf. dentifera: 9,10 & + & & & & + & + & records in SEA need to be revised \\
\hline 10 & A. guttata: $3,4,6,9,10,11$ & + & + & & + & & & \\
\hline 11 & A. intermedia: 3,4 & + & + & + & + & + & & \\
\hline 12 & A. milleri: 2 & + & & & & & & rare and local species \\
\hline 13 & A. monacantha: $2,3,4,9,10,11$ & + & & & + & & & \\
\hline 14 & A. quadrangularis: $2,3,9,10,11$ & + & + & & + & & & \\
\hline 15 & A. rectangula: $1,2,4,5,6,9,10$ & + & + & + & + & + & & \\
\hline 16 & A. verrucosa: $2,3,4,5,6,9,10,11$ & + & & + & + & + & & \\
\hline 17 & A. pulchella: 2,3 & + & & + & + & + & & \\
\hline 18 & A. sarasinorum: 9,10 & + & & & & & & \\
\hline 19 & Alonella clathratula: $2,3,9,10,11$ & + & + & + & + & & + & \\
\hline 20 & A. excisa: $1,2,3,4,9,10,11$ & + & + & + & + & + & + & cosmopolitan \\
\hline 21 & A. nana: $4,9,10$ & + & + & + & & & + & \\
\hline 22 & Acroperus harpae: 2, 3, 4, 9, 10 & + & + & + & + & & & \\
\hline 23 & Armatoalona macrocopa: 13 & + & & + & & & & $\begin{array}{l}\text { at present in oriental region, it was recorded } \\
\text { from Thailand only }\end{array}$ \\
\hline 24 & Camptocercus australis: $3,4,6,9,10,11$ & + & & + & & & & \\
\hline 25 & C. uncinatus: $1,2,5$ & + & + & + & + & + & & \\
\hline 26 & $\begin{array}{l}\text { Chydorus eurynotus: } 1,2,3,4,5,6,9 \text {, } \\
10,11\end{array}$ & + & & + & + & + & & circumtropical \\
\hline 27 & C. obscurirostris: $4,9,10,11$ & + & & + & & & & \\
\hline 28 & C. opacus: 4 & + & & + & & & & \\
\hline 29 & C.parvus: $2,3,4,5,6,9,10,11$ & + & & + & + & & & \\
\hline 30 & C.pubescens: $2,4,6,9,10,11$ & + & & & + & + & & circumtropical \\
\hline 31 & C.reticulatus: $2,4,5,9,10,11$ & + & & & & & & \\
\hline
\end{tabular}


Table 1. (continued)

\begin{tabular}{|c|c|c|c|c|c|c|c|c|}
\hline & \multirow[t]{2}{*}{ Species } & \multicolumn{6}{|c|}{ Distributions } & \multirow[t]{2}{*}{ Notes } \\
\hline & & $\mathrm{O}$ & $\mathrm{P}$ & $\mathrm{A}$ & Af & $\mathrm{N}$ & $\mathrm{Ne}$ & \\
\hline 32 & C. sinensis: $2,3,11$ & + & + & & & & & \\
\hline 33 & C. sphaericus: 9,10 & + & + & + & + & + & + & species complex, cosmopolitan \\
\hline 34 & C. ventricosus: $2,4,6,9,10,11$ & + & & & + & + & & circumtropical \\
\hline 35 & Dadaya macrops: 2, 3, 4, 6, 9, 10, 11 & + & & & + & + & & circumtropical \\
\hline 36 & Disparalona caudata: $2,9,10$ & + & & + & & & & \\
\hline 37 & D. hamata: 2, 3, 4, 6, 9, 10, 11 & + & + & + & + & + & + & cosmopolitan \\
\hline 38 & D. rostrata: 4,11 & + & + & & + & & & records in Africa need to be revised \\
\hline 39 & $\begin{array}{l}\text { Dunhevedia crassa: } 1,2,3,4,5,6,9,10 \text {, } \\
11\end{array}$ & + & + & + & + & + & + & cosmopolitan \\
\hline 40 & D. serrata: $2,3,4,6,9,10,11$ & + & & & + & + & & \\
\hline 41 & $\begin{array}{l}\text { Ephemeroporus barroisi: 1, 2, 3, 4, 5, 6, } \\
9,10,11\end{array}$ & + & & + & + & & + & circumtropical \\
\hline 42 & E. hybridus: 9, 10 & + & & & + & + & + & \\
\hline 43 & E. phintonicus: $4,9,10$ & + & & + & & & & \\
\hline 44 & E. tridentatus: 9,10 & + & & & & + & & \\
\hline 45 & $\begin{array}{l}\text { Euryalona orientalis: } 1,2,3,5,6,9,10 \text {, } \\
11\end{array}$ & + & & & + & + & & \\
\hline 46 & Graptoleberis testudinaria: 2,4 & + & + & + & + & & & \\
\hline 47 & Indialona macronyx: $2,4,9,10$ & + & & & & & & \\
\hline 48 & Karualona iberica: 9, 10 & + & + & + & + & & & \\
\hline 49 & K. karua: 11 & + & & + & & & & \\
\hline 50 & Kurzia brevilabris: 11 & + & & + & + & + & + & \\
\hline 51 & K. longirostris: $2,3,4,5,6,9,10$ & + & & + & + & & & \\
\hline 52 & Leberis diaphanus: $1,2,3,4,6,9,10,11$ & + & & + & + & + & & \\
\hline 53 & Leydigia acanthocercoides: 2, 5, 6 & + & + & & + & & & \\
\hline 54 & L. ciliata: 1,11 & + & & + & + & + & & \\
\hline 55 & L. laevis: 2 & + & & & & & & \\
\hline 56 & L. australis: 4 & + & & + & & & & \\
\hline 57 & Nicsmirnovius eximius: $6,9,10,11$ & + & & + & & & & \\
\hline 58 & Notoalona globulosa: 2, 3, 4, 9, 10, 11 & + & & & + & & & \\
\hline 59 & N. freyi: $4,9,10$ & + & & & & & & \\
\hline 60 & $\begin{array}{l}\text { Oxyurella singalensis: } 2,3,4,6,9,10, \\
11\end{array}$ & + & & & + & & & \\
\hline 61 & Pleuroxus uncinatus: 9, 10 & + & + & & & & + & \\
\hline 62 & P. quasidenticulatus: 4, 6 & + & + & + & & + & & \\
\hline 63 & P. laevis: $2,4,6,9,10,11$ & + & + & + & & & & \\
\hline 64 & $\begin{array}{l}\text { Pseudochydorus globosus: } 11 \\
\text { Family Daphniidae }\end{array}$ & + & + & + & + & + & & cosmopolitan \\
\hline & $\begin{array}{l}\text { Ceriodaphnia cornuta: } 2,3,4,5,6,9, \\
10,11\end{array}$ & + & & + & + & + & & \\
\hline & Daphnia lumholtzi: 2, 3, 5, 6, 11 & + & & + & + & & & \\
\hline
\end{tabular}


Table 1. (continued)

\begin{tabular}{|c|c|c|c|c|c|c|c|c|}
\hline & \multirow[t]{2}{*}{ Species } & \multicolumn{6}{|c|}{ Distributions } & \multirow{2}{*}{ Notes } \\
\hline & & $\mathrm{O}$ & $\mathrm{P}$ & A & Af & $\mathrm{N}$ & $\mathrm{Ne}$ & \\
\hline 67 & $\begin{array}{l}\text { Scapholeberis kingi: } 2,3,4,5,6,9,10, \\
11\end{array}$ & + & & + & + & + & & \\
\hline 68 & Simocephalus exspinosus: $2,3,11$ & + & + & + & & & & \\
\hline 69 & S. heilongjiangensis: $2,3,4,6,9,10,11$ & + & & & & & & \\
\hline 70 & S. vetulus: 2 & + & + & + & + & + & & \\
\hline 71 & $\begin{array}{l}\text { S. serrulatus: } 2,3,4,6,9,10,11 \\
\text { Family Ilyocryptidae }\end{array}$ & + & + & + & + & + & & \\
\hline 72 & Ilyocryptus cf. bhardwaji: 7 & + & & & & + & & \\
\hline 73 & I. cf. raridentatus: 7 & + & & & & + & & \\
\hline 74 & I. spinifer: $2,3,4,5,6,9,10,11$ & + & & + & + & + & & \\
\hline 75 & I. thailandensis: 7 & + & & & & & & at present, it was recorded from Thailand only \\
\hline 76 & $\begin{array}{l}\text { I. isanensis: } 12 \\
\text { Family Macrothricidae }\end{array}$ & + & & & & & & at present, it was recorded from Thailand only \\
\hline 77 & Grimaldina brazzai: 4, 5, 11 & + & & + & + & + & & circumtropical \\
\hline 78 & Guernella raphaelis: $2,4,6,9,10,11$ & + & & + & + & + & & circumtropical, including China \\
\hline 79 & Macrothrix cf. laticornis: 2, 4, 5, 6, 9, 10 & + & + & + & & + & & records in SEA need to be revised \\
\hline 80 & M. cf. gauthieri: 10 & + & & + & + & & & records in SEA need to be revised \\
\hline 81 & M. paulensis: 2, 9, 10 & + & & & & + & & $\begin{array}{l}\text { at present in SEA, it was recorded from } \\
\text { Thailand only }\end{array}$ \\
\hline 82 & M. malaysiensis: 9,10 & + & & + & & & & \\
\hline 83 & M. odiosa: $3,4,9,10,11$ & + & & + & & & & \\
\hline 84 & M.pholpunthini: 8 & + & & & & & & at present, it was recorded from Thailand only \\
\hline 85 & M. spinosa: $1,2,3,4,6,9,10,11$ & + & & + & + & + & & circumtropical \\
\hline 86 & M. cf. superaculeata: 9,10 & + & & & & + & & records in SEA need to be revised \\
\hline 87 & M. triserialis: $1,2,4,5,6,9,10,11$ & + & & + & + & + & & circumtropical \\
\hline 88 & $\begin{array}{l}\text { Strebloceras pygmaeus: } 2,4,5,9,10 \\
\text { Family Moinidae }\end{array}$ & + & & & & + & & \\
\hline 89 & Moina micrura: 2, 3, 4, 5, 6, 9, 10, 11 & + & + & + & + & + & + & \\
\hline 90 & $\begin{array}{l}\text { Moinodaphnia macleayi: 2, 4, 9, 10, } 11 \\
\text { Order Ctenopoda } \\
\text { Family Sididae }\end{array}$ & + & & + & + & + & + & circumtropical \\
\hline 91 & Diaphanosoma dubia: 11 & + & + & & & & & mainly in Far East \\
\hline 92 & D. excisum: $1,2,3,4,5,6,9,10,11$ & + & & + & + & & & circumtropical \\
\hline 93 & D. volzi: $2,3,4,11$ & + & & + & + & & & rare species \\
\hline 94 & D. sarsi: $2,3,6,9,10$ & + & + & + & + & + & & circumtropical \\
\hline 95 & Latonopsis australis: 2, 3, 4, 6, 9, 10, 11 & + & & + & + & + & + & species complex, cosmopolitan \\
\hline 96 & Pseudosida bidentata: 2, 4, 6, 9, 10, 11 & + & & + & + & + & + & \\
\hline 97 & P. ramosa: $2,9,10$ & + & & + & & + & & \\
\hline 98 & Sarsilatona serricauda: 4 & + & + & & & + & + & \\
\hline 99 & Sida crystallina: $3,9,10,11$ & + & + & + & & + & & \\
\hline
\end{tabular}




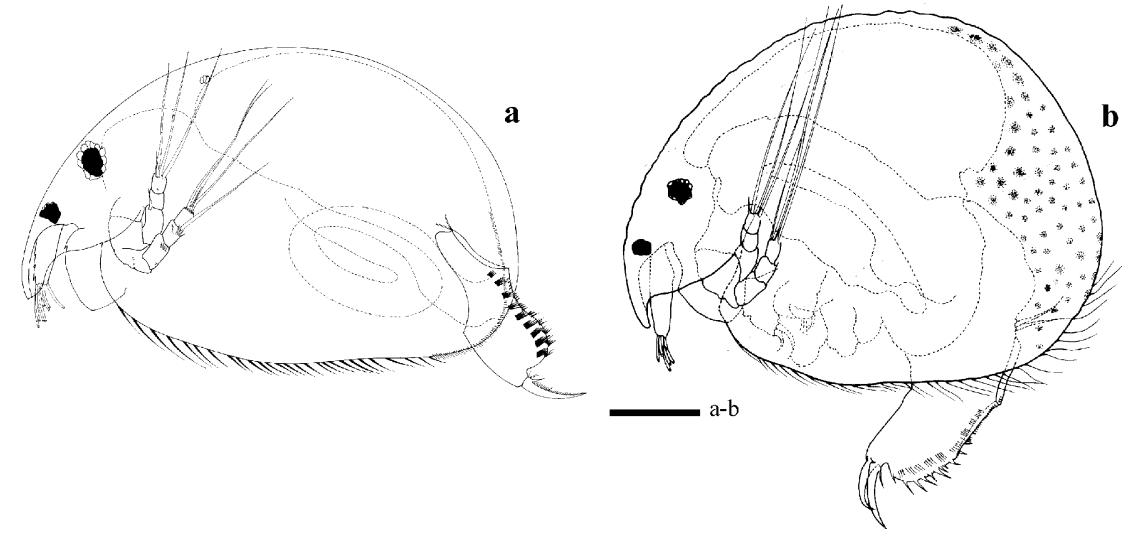

Figs 2a-b. Alona verrucosa Sars, 1901: parthenogenetic females from Thungtong swamp (S019), Suratthani Province, southeastern Thailand.

Figures a-b, adult females in lateral view. Scale bars denote $100 \mu \mathrm{m}$.

However, after checking specimens from southern (PK1SM003-01) and northeastern Thailand (PK1SM003-02), Malaysia (PK1SM003-03) and Singapore (PK1SM003-04), all records were found to belong to A. cheni (Fig. 3a), on account of the semi-circular pockets below the lateral pores (Figs $3 b-c)$, the main character that separates $A$. costata from $A$. cheni (Sinev 1999). It is probable that all previous Thai records of $A$. costata actually represent $A$. cheni, and the former species is not present in the region.

Alona archeri Sars, 1888 was originally described from Australia. After its initial description it was reported from Indonesia (Brehm 1933), Tadzhikistan (Mukhamediev 1986), Queensland, New South Wales and Tasmania (Smirnov \& Timms 1983). Sinev redescribed it in 2002, based on G. O. Sars' original sample and one slide from Australia. Pholpunthin (1997) recorded it from Thalenoi marsh (S041), Pattalung Province, southern Thailand, the first record from Thailand, but he did not illustrate its morphology. Upon checking, it was found that the specimens from S060 (PK1SM001-02) and specimens recorded as $A$. aff. karelica from $\mathrm{S} 042$ (PK1SM001-01, in Maiphae 2005 and Maiphae et al. 2005) are all A. archeri (Figs 4-5), on account of their narrow postabdomen (Figs 4i-j) with parallel margins, well developed denticles on distal angle, proximally replaced by short setules, fascicles narrow and wide gaps between them, and long basal spine of postabdominal claw ( $1 / 3$ or $1 / 4$ of claw). The latest character separates $A$. archeri from true A. karelica (spine 1/5 of claw or hardly visible).

There are differences between specimens from Australia (Sinev 2002) and southern Thailand: 1) length 1.41.6 times maximum height in Sinev (2002) but about 1.41.8 times in Thai specimens (Figs 4a-c); 2) antennule not reaching tip of rostrum in Sinev (2002) but reaching that tip in Thai specimens (Fig. 4b); 3) longest aestetasc about 0.5 length of antennule in Sinev (2002) but about 0.8 length of antennule in Thai specimens (Fig. 4e); 4) labral keel with re-curve rounded apex in Sinev (2002) but more round in Thai specimens (Fig. 4d); 5) basal spine of postabdomen 1/3 of claw length in Sinev (2002) but $1 / 4$ in the present study (Figs $4 \mathrm{i}-\mathrm{j})$, and 6$) 1^{\text {st }}$ and $2^{\text {nd }}$ scrapers of the same length in Sinev (2002) but $1^{\text {st }}$ scraper shorter than $2^{\text {nd }}$ in Thai specimens (Fig. 5b). We here refrain from giving these a taxonomic weight.

Alona cf. cambouei (Figs 6a-e) from the South (PK1SM002-01) shows characters different from A.pulchella and shared with A. cambouei, as understood by Sinev (1999), e.g. 3 central pores round and disconnected. Specimens from the northeast (PK1SM002-02) present the same. However, we still lack data on specimens from other parts of country and, because A. cambouei was originally described from Madagascar, it should be redescribed from topotypical material to set a modern standard for comparison. Thus, we keep both species in the list till further comparisons can be made.

\section{Notes on biogeography}

The distribution of Thai Cladocera varies from cosmopolitan to a range shared between several regions, to one restricted to a single region or even habitat (table 1). True cosmopolitan species are few (Frey 1987, Dumont 1980, Dumont \& Negrea 2003). As their morphological definition improves, species-groups can be distinguished, composed of related, but distinct taxa, each with a limited geographical range. On the other hand taxa such as families are essentially cosmopolitan, because the ecologi- 


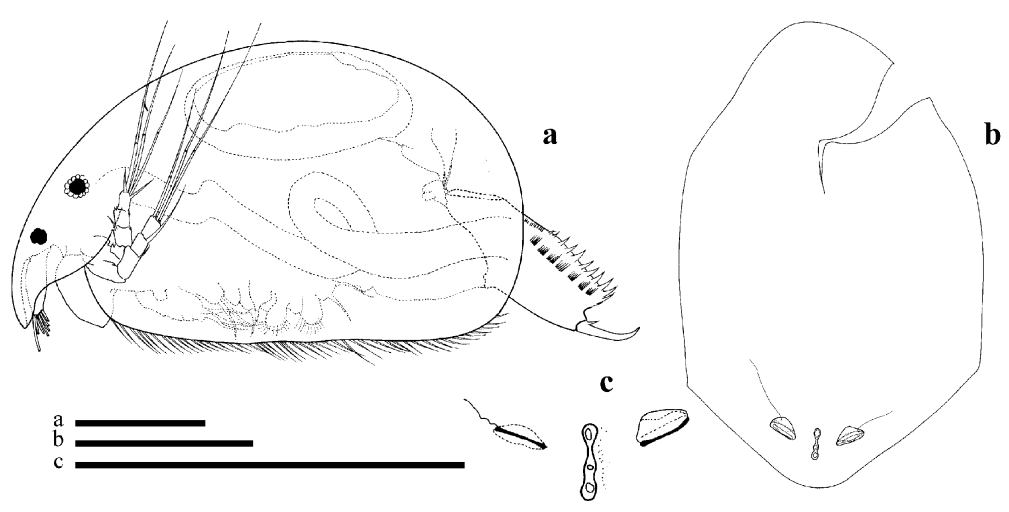

Figs 3a-e. Alona cheni Sinev, 1999: parthenogenetic female from Thungtong swamp (S019), Suratthani Province, southeastern Thailand. Figure a, adult female in lateral view; Figures b-c, head shield and its head pores. Scale bars denote $100 \mathrm{~m}$.

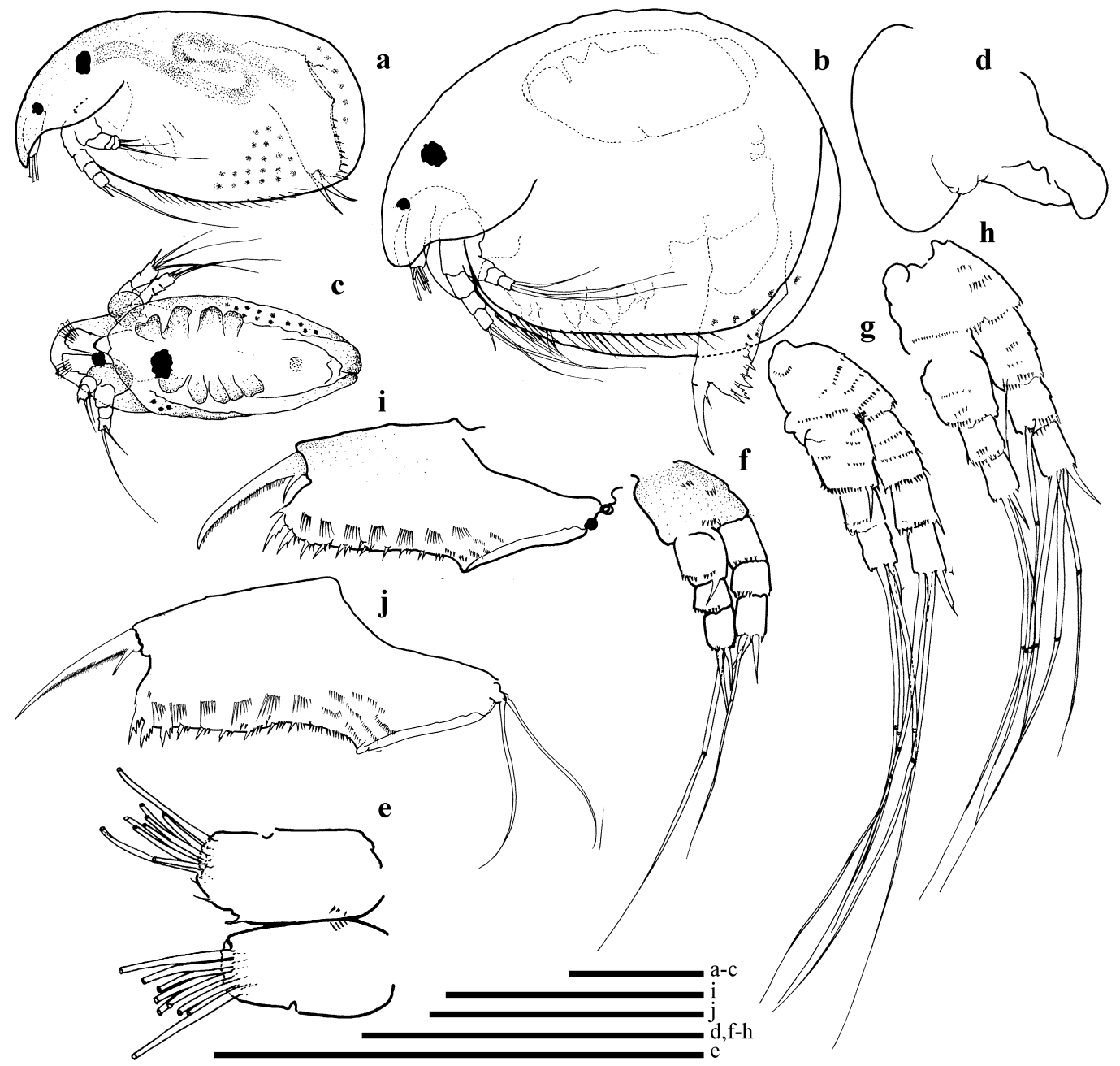

Figs 4a-j. Alona archeri Sars, 1888: parthenogenetic females from Kalai swamp (S060), Phang-nga Province, southwestern Thailand. Figures ab, adult females in lateral view; Figure c, adult female in ventral view; Figure d, labrum; Figure e, antenna 1; Figures f-h, antenna 2; Figures ij, postabdomen. Scale bars denote $100 \mathrm{~m}$. 


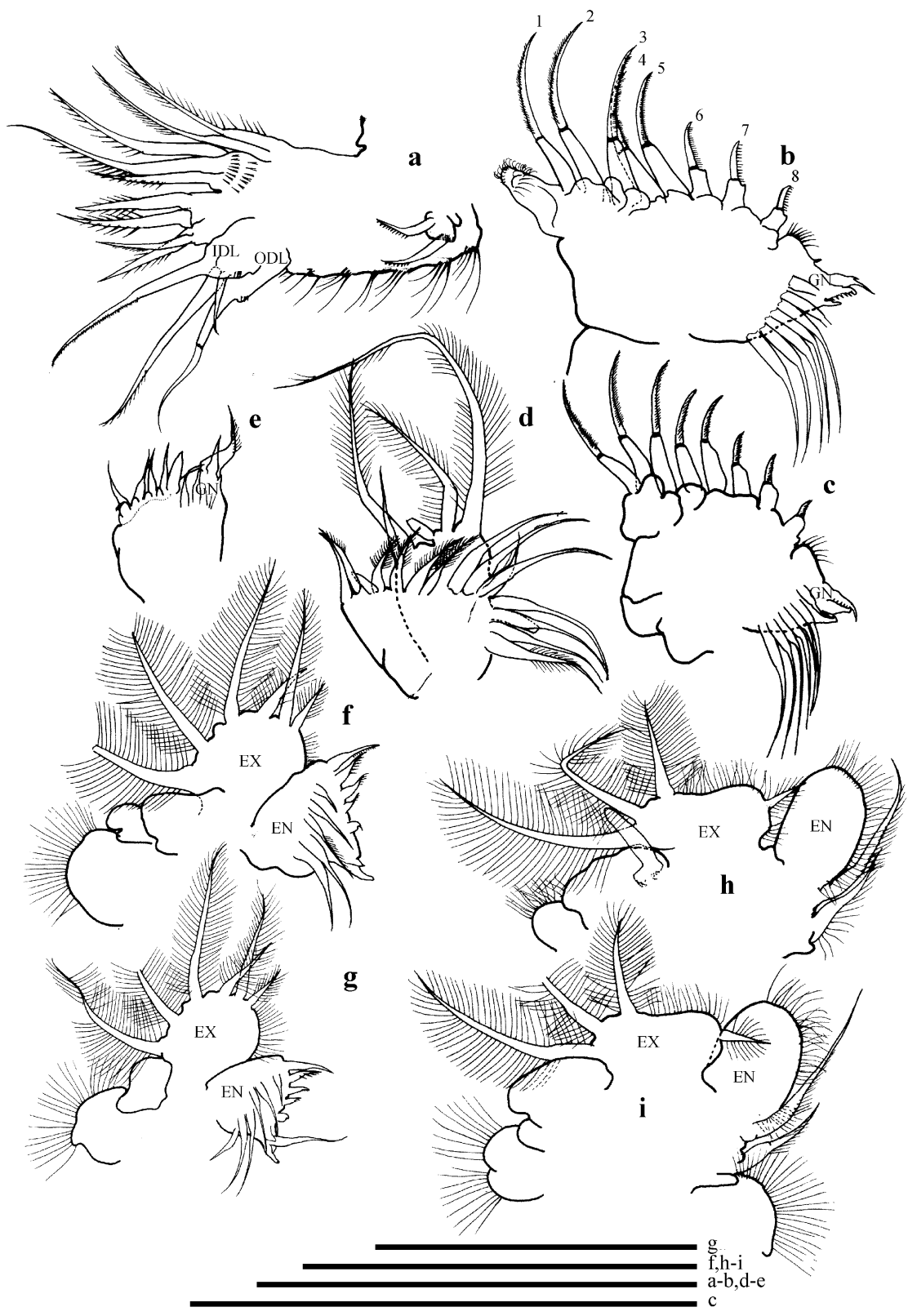

Figs 5a-i. Alona archeri Sars, 1888: appendages of parthenogenetic females from Kalai swamp (S060), Phang-nga Province, southwestern Thailand. Figure a, trunk limb 1; Figures b-c, trunk limb 2; Figures d-e, trunk limb 3; Figures f-g, trunk limb 4; Figures h-i, trunk limb 5. Scale bars denote $100 \mathrm{~m}$.

cal diversity within these groups is broad enough for them to exist in most aquatic habitats, and also because these groups are old enough to have had opportunities to colonize the world.
Of the 99 species, 13 are restricted to oriental region, 14 are circumtropical (Bosmina longirostris, Bosminopsis deitersi, Chydorus eurynotus, $C$. pubescens, $C$. ventricosus, Dadaya macrops, Ephemeroporus barroisi, 


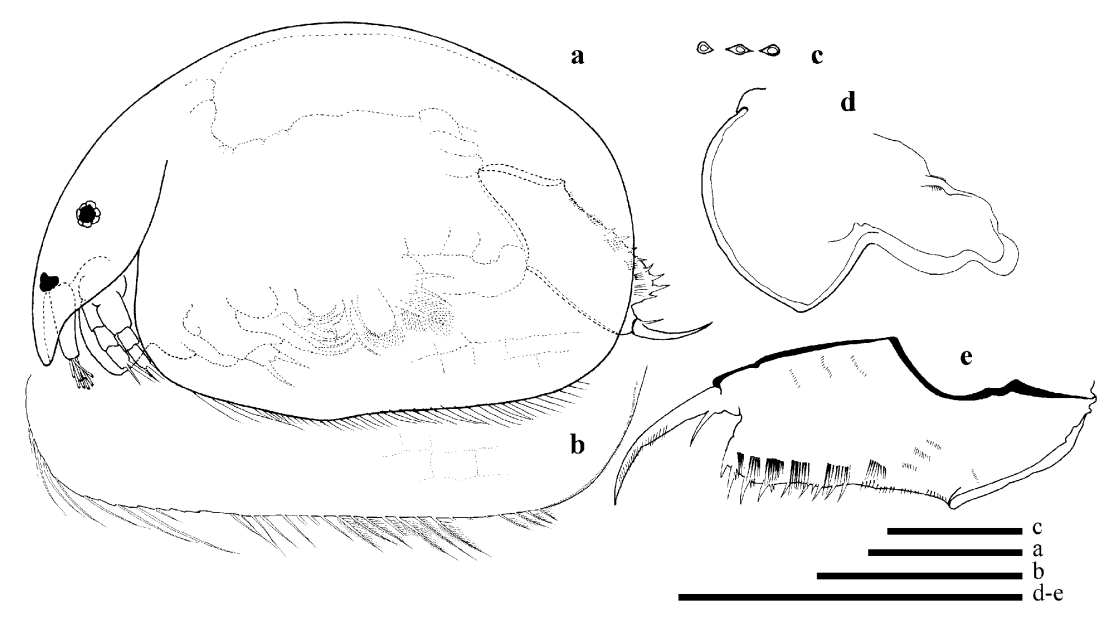

Figs 6a-e. Alona cf. cambouei Guerne \& Richard, 1893: parthenogenetic females from Maikhao peatswamp (S028), Phuket Province, southwestern Thailand. Figure a, adult female in lateral view; Figure b, ventral margin of valve; Figure c, head pores; Figure d, labrum; Figure e, postabdomen. Scale bars denote $100 \mathrm{~m}$.

Grimaldina brazzai, Guernella raphaelis, M. spinosa, M. triserialis, Moinodaphnia macleayi Diaphanosoma excisum and $D$. sarsi), three have a neotropical affinity (Ephemeroporus tridentatus, Macrothrix cf. laticornis and Macrothrix paulensis), six have a wide range (Bosmina longirostris, Alonella excisa, Chydorus sphaericus, Dunhevedia crassa, Pseudochydorus globosus and Latonopsis australis) and three are possible endemics (Ilyocryptus thailandensis, I. isanensis and Macrothrix pholpunthini). The class restricted to a single region contains about $12 \%$ of all species: Bosmina fatalis, B. meridionalis, Alona cheni, A. milleri, Chydorus reticulatus, Indialona macronyx, Leydigia laevis, Notoalona freyi, Simocephalus heilongjiangensis, Ilyocryptus thailandensis, I. isanensis, Macrothrix odiosa and M. pholpunthini. This may reflect the isolation of the region since the late Precambrian (Scotese 2001).

Some taxa found in Thailand have been recorded disjunctly from other regions, including the Holartic, Mediterranean and even the Neotropics as mentioned above: Alonella nana, Ephemeroporus tridentatas, $E$. hybridus, E. phintonicus, Leydigiopsis sp., Macrothrix cf. laticornis, $M$. cf. superaculeata, M. paulensis and Streblocerus pygmaeus. However, most of them except A. nana are rare. One hypothesis to explain the existence of these species in Thailand is that they are relicts of a continuous Pre-Pleistocene distribution rather than descendants of inocula that reached the rainforest during the humid periods of the Pleistocene (Korovchinsky, 2006). A similar species composition occurs in some acid, black waters, covered with sedge, in Brazil (Van Damme 1998) and in southern Thailand. That some Thai (e.g. Leydigiopsis sp.) and South American taxa found here are congeneric and related but not conspecific rules out recent passive dispersal. Coupled to the fact that cladocerans evolve slowly, a Gondwanian origin of such taxa appears likely, combined with a Cenozoic extinction of similar taxa in the intervening continent of Africa (Chiambeng \& Dumont 2005).

Macrothrix pholpunthini Kotov, Maiphae \& Sanoamuang, 2005, Ilyocryptus thailandensis Kotov \& Sanoamuang, 2005 and I. isanensis Kotov, Stifter \& Sanoamuang, 2005 are apparently endemic although it cannot be excluded that further faunistic study in neighbouring countries may find them there as well. At least some of the still unidentified species may be new species, and may in future increase the number of endemics in the country.

Daphnia is rare, with only $D$. lumholtzi on record (Sanoamuang 1998, Saeng-aroon 2001, Sa-ardrit 2002, Sa-ardrit \& Beamish 2005). This is a multifactor phenomenon. Dumont (1980) and Chiambeng \& Dumont (2005) attribute its scarcity in tropical lowlands to high levels of predation by fish, more numerous in the tropics than elsewhere. Also, the temperature-dependency of predation is a pivotal variable (Dumont 1994), as well as the absence of seasonal succession in the tropics, exacerbating not only predation but also competition. Finally, the absence of suitable carriers for passive dispersal (e.g. migratory birds) in the rare environments suitable for Daphnia in the tropics (e.g. high mountain lakes) makes its colonisation there improbable and slow. 
From all the above, it appears that Alona is currently the best studied group in Thailand but a number of other genera and species still await revision. Particularly, chydorids such as Chydorus, Ephemeroporus and Pleuroxus show a high diversity in Thailand that merits further scrutiny.

\section{Acknowledgements}

The authors thank Prof. Dr. La-orsri Sanoamuang from Khon Kaen University for valuable data on species richness of northeast Thailand. This work was supported by Thailand Research Fund (MRG4980039). The study was carried out under the General Science Department and the Excellence Centre for Biodiversity of Peninsular Thailand (CBIPT), faculty of Science, Prince of Songkla University.

\section{References}

Adamowicz S.J. \& Purvis A. 2005. - How many branchiopod crustacean species are there? Quantifying the components of underestimation. Global. Ecol. Biogeogr, 14, 455-468.

Boonsom J. 1984. — The freshwater zooplankton of Thailand (Rotifera and Crustacea). Hydrobiologia, 113, 223-229.

Brehm V. 1983. - Mitteilungen von der Wallacea-Expedition Woltereck. Mitteilung V. Phyllopoden. Mitteilung VI. Die Alona and Alonella Arten von Dagiangan. Mitteilung VII. Neue und wenig bekannte Entomostraken. Zool. Anz, 104, 31-40, 77-84, 130-142.

Chiang S-C \& Du N-S. 1979. - Fauna Sinica. Crustacea. Freshwater Cladocera. Science Press, Academia Sinica, Peking, 297 p.

Chiambeng G.Y. 2004. - Taxonomy and Biogeography of Branchiopoda (Crustacea: Anomopoda, Ctenopoda and Cyclestherida) from the rain forest in Cameroon, Central Africa. Thesis. Ghent University, Ghent, Belgium. 307 p.

Chiambeng G.Y. \& Dumont H.J. 2005. - The Branchiopoda (Crustacea: Anomopoda, Ctenopoda and Cyclestherida) of the rain forests of Cameroon, West Africa: low abundances, few endemics and a boreal-tropical disjunction. J. Biogeogr, 32, 1611-1620.

Dumont H.J. 1980. - Zooplankton and the science of biogeography: the example of Africa. Evolution and ecology of zooplankton communities (ed. W. C. Kerfoot). University Press of New England, 685-696.

Dumont H.J. 1994. - On the diversity of the cladocera in the tropics. Hydrobiologia 272, 27-38.

Dumont H.J. \& Van de Velde I. 1977. - Cladocères et Conchostracés recoltés par le professeur Th. Monod dans la moyenne vallée du Niger en decembre 1972 et janvier 1973. Bulletin de l' Institut Fondamental de l' Afrique Noire, A39, 7593.

Dumont H.J. \& Negrea S.V. 2003. - Introduction to the class Branchiopoda. In H. J. Dumont (ed.), Guides to the identification of the microinvertebrates of the Continental Waters of the World. Backhuys, the Netherlands, 19, $398 \mathrm{p}$.

Fernando C.H. 1980. — The freshwater zooplankton of Sri Lanka, with a description of tropical freshwater zooplankton communities. Int. Rev. Hydrobiol., 65, 85-125.

Frey D.G. 1987. - The taxonomy and biogeography of the Cladocera. Hydrobiologia, 145, 5-17.

Idris B.A.G. 1983. - Freshwater zooplankton of Malaysia (Crustacea: Cladocera). Perenbit University, Pertanian, Malaysia, $153 \mathrm{p}$.
Idris B.A.G. \& Fernando C.H. 1981. - Cladocera of Malaysia and Singapore with new records, redescriptions and remarks on some species. Hydrobiologia 77, 233-256.

Korovchinsky N.M. 2006. - The Cladocera (Crustacea: Branchiopoda) as a relict group. Zool. J. Linn. Soc-Lond, 147, 109-124.

Kotov A.A. 2003. - Notes on Aloninae Dybowski \& Grochoski, 1894 emend. Frey, 1967 (Cladocera: Anomopoda: Chydoridae): 1. Translocation of Alona incredibilis Smirnov, 1984 to the genus Nicsmirnovius Chiambeng \& Dumont, 1999. Arthropoda Selecta, 12, 167-170.

Kotov A.A. \& Dumont H.J. 2000. Analysis of the Ilyocryptus spinifer s. lat. species group (Anomopoda, Branchiopoda), with description of a new species. Hydrobiologia, 428,85-113.

Kotov A.A. \& Hollwedel W. 2004. - Revision of the Macrothrix paulensis species group (Anomopoda, Cladocera, Branchiopoda) in Neotropics, with description of M. brandorffi n. sp. Arch. Hydrobiol. Suppl. Monogr. Stud, 151, 125-159.

Kotov A.A. \& Sanoamuang L. 2004a. - Comments on the morphology of Nicsmirnovius eximius (Kiser, 1948) (Aloninae, Anomopoda, Cladocera) in Thailand, with a description of its male. Hydrobiologia, 519, 117-125.

Kotov A.A. \& Sanoamuang L. 2004b. - Ilyocryptus thailandensis sp. nov. (Cladocera: Anomopoda: Ilyocryptidae) from North Thailand. Int. Rev. Hydrobiol, 89, 206-214.

Kotov A.A., Maiphae S. \& Sanoamuang L. 2005a. - Revision of the Macrothrix paulensis like-species (Anomopoda, Cladocera, Branchiopoda) in Asia, and phylogeny of the paulensis-group. Arch. Hydrobiol. Suppl. Monogr. Stud, 151/3, 269-299.

Kotov A.A., Stifter P. \& Sanoamuang L. 2005b. — Notes on the genus Ilypcryptus Sars, 1862 (Cladocera: Anomopoda: Ilyocryptidae). 8. Ilyocryptus isanensis sp.n. from Northeast Thailand. Arthropoda Selecta, 14, 229-239.

Maiphae S. 2005. - Taxonomy and Biogeography of the Cladocera from Southern Thailand, with specific reference to Alona Baird, 1843 and Macrothrix Baird, 1843. Ph.D. thesis. Prince of Songkla University, Thailand, 314 p.

Maiphae S., Pholpunthin P. \& Dumont H.J. 2005. - Species richness of the Cladocera (Branchiopoda: Anomopoda and Ctenopoda) in southern Thailand, and its complementarity with neighboring regions. Hydrobiologia, 537, 147-156.

Mammaril C.A. \& Fernando C.H. 1978. - Freshwater zooplankton of the Philippines (Rotifera, Cladocera and Copepoda). Nat. Appl. Sci. Bul., 30, 109-221.

Michael R.G. \& Sharma B.K. 1988. - Fauna of India and adjacent countries: Indian Cladocera (Crustacea: Branchiopoda: Cladocera). Technical and General Press, India, $262 \mathrm{pp}$.

Mukhamediev A.M. 1960. New species of Cladocera from ricefields of the Fergana Valley. Uzeb. biol. Zhur., 3, 35-38.

Pholpunthin P. 1997. - Freshwater zooplankton (Rotifera, Cladocera and Copepoda) from Thale-Noi, South Thailand. J. Sci. Soc. Thailand, 23, 23-34.

Pipatcharoenchai W. 2001. - Diversity of Zooplankton in Changwat Kanchanaburi. Thesis. Kasetsart University, 286 pp.

Sa-ardrit P. 2002. - Diversity and distribution of freshwater cladocera from Trang Province. Thesis. Prince of Songkhla University, $98 \mathrm{p}$.

Sa-ardrit P \& Beamish F.W.H. 2005. - Cladocera diversity, abundance and habitat in a western Thailand stream. Aquat. Ecol., 39, 353-365.

Saeng-aroon C. 2001. - Species diversity and abundance of Cladocera in Lake Kud-Thing, Nong Khai Province. M.Sc. thesis, Graduate School in Biology, Khon Kaen University, Khon Kaen, Thailand, $105 \mathrm{p}$. 
Sanoamuang L. 1998. - Contributions to the knowledge of the Cladocera of northeast Thailand. Hydrobiologia, 362, 45-53.

Sanoamuang L. \& Faitakum S. 2005. - Species diversity and distribution of cladocerans and copepods in the floodplain of the Mun River. KKU Research Journal, 10, 106-113.

Scotese C.R. 2001. - Atlas of Earth History, Volume 1, Paleogeography. PALEOMAP Project, Arlington, Texas, $52 \mathrm{p}$.

Sinev A.Y. 1999. - Alona costata Sars, 1862 versus related paleotropical species: the first example of close relations between species with a different number of main head pores among Chydoridae (Crustacea: Anomopoda). Arthropoda Selecta, 8, 131-148.

Sinev A.Y. 2002. - Redescription of an Australian cladoceran, Alona archeri Sars, 1888 (Branchiopoda: Anomopoda: Chydoridae). Arthropoda Selecta, 11, 247-254.

Sinev A.Y., Nachai S. \& Sanoamuang, L. 2007. Occurrence of the Australian cladoceran Armatalona macrocopa (Sars, 1894)
(Cladocera: Anomopoda: Chydoridae) in Thailand. Invrtebr. Zool., 4: 25-29.

Smirnov N. N. \& Timms B.V. 1983. A revision of the Australian Cladocera. Rec. Aust. Mus. Suppl., 1, 1-132.

Van Damme K. 1998. - Conchostraca and 'Cladocera' (Crustacea) of dune pools in the Lençóis Maranhenses, NEBrazil (in Dutch). Unpublished thesis, Ghent University, 179 p.

Van Damme K., Chiambeng G., Maiphae S. \& Dumont H.J. 2003. - New species in the rheophilous genus Nicsmirnovius Chiambeng \& Dumont, 1999 (Branchiopoda: Anomopoda: Chydoridae) and reassignment of Alona eximia Kiser, 1948 and Alonella fitzpatricki Chien, 1970, Hydrobiologia, 499, 25-49.

Van Damme K., Kotov A.A. \& Dumont H.J. 2005. — Redescription of Leydigia parva Daday, 1905 and assignment to Parvalona gen. nov. (Cladocera: Anomopoda: Chydoridae), J. Nat. Hist., 39, $2125-2136$ 
